\title{
PENGARUH MODEL PEMBELAJARAN CREATIVE PROBLEM SOLVING TERHADAP KEMAMPUAN MEMECAHKAN MASALAH FISIKA PADA SISWA KELAS XI SMA NEGERI 4
} PALU

\author{
Hariawan ${ }^{1)}$, Kamaluddin ${ }^{2)}$, dan Unggul Wahyono ${ }^{3)}$ \\ Email: Hariawanfisika@yahoo.co.id \\ Program Studi Pendidikan Fisika, Jurusan Pendidikan MIPA, Universitas Tadulako, \\ Jl. Soekarno Hatta KM. 9.
}

\begin{abstract}
Abstrak- Penelitian ini bertujuan menguji signifikansi pengaruh model pembelajaran creative problem solving terhadap kemampuan memecahkan masalah fisika yang dilihat dari perbedaan hasil postest di kelas eksperimen dan kelas kontrol. Desain penelitian adalah eksperimen kuasi dengan Pretest-posstest Equivalent Group Design. Populasi penelitian adalah seluruh siswa kelas XI IPA SMA Negeri 4 palu. Teknik pengambilan sampel adalah purposive sampling. Kelas XI IPA-A sebagai kelas eksperimen dan kelas XI IPA-F sebagai kelas kontrol. Instrumen digunakan berupa uraian tes. Analisis data menggunakan Uji t dua pihak pada taraf signifikansi $5 \%$ dan $\mathrm{dk}=70$ dengan uji prasyarat normalitas dan homogenitas. Hasil uji statistik diperoleh $t_{\text {hitung }}=3,18$ dan $t_{\text {tabel }}=1,99$ dengan kriteria terima $\mathrm{H}_{0}$ jika $-1,99<\mathrm{t}<1,99$ dan tolak $\mathrm{H}_{1}$ dalam hal lainnya. Nilai $\mathrm{t}_{\text {hitung }}$ berada diluar penerimaan $\mathrm{H}_{\mathrm{o}}$ sehingga $\mathrm{H}_{1}$ diterima dengan kesimpulan terdapat pengaruh model pembelajaran creative problem solving yang signifikan terhadap kemampuan siswa dalam memecahkan masalah fisika.
\end{abstract}

Kata Kunci: Creative Problem Solving; Kemampuan Memecahkan Masalah Fisika.

\section{PENDAHULUAN}

Pembelajaran fisika adalah pembelajaran yang tidak mengabaikan hakikat fisika sebagai sains. Hakikat sains yang dimaksud meliputi produk, proses, dan sikap ilmiah. Pembelajaran fisika seharusnya dapat memberikan pengalaman langsung pada siswa sehingga menambah kemampuan dalam mengkonstruksi, memahami, dan menerapkan konsep yang telah dipelajari. Dengan demikian, siswa akan terlatih menemukan sendiri berbagai konsep secara holistik, bermakna, otentik serta aplikatif untuk kepentingan pemecahan masalah [1]. Hal ini pula yang menjadi salah satu tujuan pembelajaran fisika itu sendiri, yaitu mengembangkan kemampuan bernalar dalam berpikir analisis induktif dan deduktif dengan menggunakan konsep dan prinsip fisika untuk menjelaskan berbagai peristiwa alam dan menyelesaikan masalah baik secara kualitatif dan kuantitatif [2].

Pada dasarnya, kebanyakan guru fisika hanya mengandalkan pembelajaran yang berpusat pada guru dengan perangkat pembelajaran yang hanya mengandalkan buku acuan tanpa menggunakan sarana pembelajaran lainnya, seperti laboratorium, perpustakaan, media pembelajaran, lingkungan sekitar maupun internet yang begitu jarang untuk dimanfaatkan sebagai salah satu sumber informasi belajar. Pembelajaran hanya berpusat pada pemberian informasi tanpa memperhatikan nilai-nilai yang terdapat dalam kurikulum berdampak pada kurangnya kemampuan siswa dalam 
mengembangkan dan mengaplikasikan teori yang mereka peroleh.

Mengatasi permasalahan yang dihadapi pada proses pembelajaran fisika maka perlu ada perubahan pada proses pembelajaran yang berpusat kepada guru menjadi berpusat pada siswa. Perlu dikembangkan pengalaman belajar melalui pendekatan dan inovasi yang mengaitkan antara materi pelajaran dengan permasalahan yang dihadapi serta pemanfaatan sumber belajar secara optimal. Keterlibatan langsung siswa dalam proses pembelajaran diharapkan dapat meningkatkan hasil belajar dan dapat meningkatkan keterampilan berpikir dalam memecahkan masalah [3]. Salah satu solusi yang bisa ditawarkan adalah pembelajaran konstruktif dan berpusat pada pemecahan masalah yaitu penerapan model pembelajaran Creative Problem Solving.

Creative problem solving (pemecahan masalah kreatif) dalam penyelesaian problematik maksudnya segala cara yang dikerahkan oleh seseorang dalam berpikir kreatif, dengan tujuan menyelesaikan suatu permasalahan secara kreatif. Dalam implementasinya, Creative problem solving dilakukan melalui solusi kreatif. Creative problem solving dibangun atas tiga macam komponen penting, yaitu: ketekunan, masalah dan tantangan. Creative problem solving berusaha mengembangkan pemikiran divergen, berusaha mencapai berbagai alternatif dalam memecahkan suatu masalah. Selain itu, dalam implementasinya pun lebih banyak menempatkan para pendidik sebagai fasilitator, motivator dan dinamisator belajar baik secara individu maupun secara berkelompok.

Berdasarkan hasil penelitian terdahulu diperoleh hasil penelitian yang relevan dimana peneliti tidak memihak pada salah satu model baik model creative problem solving maupun Direct Instruction. Penelitian itu diantaranya Noortsani [4] menyatakan bahwa peningkatan kemampuan pemecahan masalah matematis siswa yang belajar matematika dengan pendekatan Creative Problem Solving lebih baik secara signifikan daripada siswa yang memperoleh pembelajaran matematika secara konvensional dan Nur Hidayati, A [5] menyatakan bahwa rata-rata hasil belajar matematika peserta didik yang diajar dengan pembelajaran Direct Instruction lebih tinggi.

Beradasarkan uraian di atas, peneliti berkeinginan untuk melakukan penelitian model pembelajaran creative problem solving pada materi elastisitas dan gerak harmonik sederhana. Kedua materi tersebut merupakan saah satu bagian dari mata pelajaran fisika yang diajarkan di kelas XI SMA yang materinya banyak berkaitan dengan kehidupan sehari-hari. Keaktifan dan kekreatifan siswa dalam kegiatan belajar mengajar dengan menghadirkan fenomena alam dan pengalaman yang dimiliki siswa diharapkan mampu menghasilkan beragam ide-ide masalah yang biasa dijumpai dan mampu memecahkanya dengan solusi yang kreatif. Model pembelajaran creative problem solving berpusat pada pemecahan masalah secara kreatif diharapkan membuat siswa mampu mengembangkan kemampuannya dalam menyelesaikan masalah dalam kehidupan sehari-hari yang berkaitan dengan materi elastisitas dan gerak harmonik sederhana.

\section{METODE PENELITIAN}

Penelitian ini merupakan penelitian eksperimen quasi dengan mengambil dua kelas secara purposive sampling pada sekolah SMA Negeri 4 Palu. Kedua kelas ini yaitu kelas XI IPA A sebagai kelas eksperimen yang mengikuti model Pembelajaran Creative Problem Solving dan kelas XI IPA F sebagai kelas kontrol yang mengikuti model Pembelajaran Direct Instruction. Ruang lingkup dalam penelitian ini hanya mencakup pada kemampuan siswa dalam memecahkan masalah fisika pada materi elastisitas dan hukum Hooke.

Data yang diambil dari penelitian ini yaitu kemampuan siswa dalam memecahkan masalah fisika yang diperoleh dengan memberikan tes uraian pada akhir materi pembelajaran. Lebih jelasnya desain penelitian yang digunakan dalam penelitian ini adalah seperti pada tabel 1.

Tabel 1: Desain Penelitian : The non ekivalen pretest-postest design

\begin{tabular}{|l|c|c|c|}
\hline \multicolumn{1}{|c|}{ Group } & Tes Awal & Perlakuan & Tes Akhir \\
\hline $\begin{array}{l}\text { Kelas } \\
\text { Eksperimen }\end{array}$ & $\mathrm{O}$ & $\mathrm{X}_{1}$ & $\mathrm{O}$ \\
\hline Kelas Kontrol & $\mathrm{O}$ & $\mathrm{X}_{2}$ & $\mathrm{O}$ \\
\hline
\end{tabular}

(Sumber: Sugiyono, 2009) [6] 
Keterangan :

$\mathrm{X}_{1}$ : Model pembelajaran creative problem solving

$\mathrm{X}_{2}$ : Model pembelajaran konvensional.

O : Tes Awal dan tes akhir

\section{HASIL DAN PEMBAHASAN}

\section{a. Deskripsi Skor Kemampuan Memecahkan}

\section{Masalah Fisika}

Hasil tes kemampuan memecahkan masalah fisika berdasarkan tes awal dan tes akhir pada kelas ekperimen dan kelas kontrol dapat dilihat pada tabel 2.

Tabel 2 : Deskripsi Skor tes kemampuan memecahkan masalah fisika pada kelas eksperimen dan kelas kontrol

\begin{tabular}{|l|c|c|c|c|}
\hline \multirow{2}{*}{ Uraian } & \multicolumn{2}{|c|}{ Pretest } & \multicolumn{2}{c|}{ Posttest } \\
\cline { 2 - 5 } & \multicolumn{2}{|c|}{ Kelas } & \multicolumn{2}{c|}{ Kelas } \\
\cline { 2 - 5 } & $\begin{array}{c}\text { Eksperi } \\
\text { men }\end{array}$ & $\begin{array}{c}\text { Kontro } \\
\text { I }\end{array}$ & $\begin{array}{c}\text { Eksperi } \\
\text { men }\end{array}$ & Kontrol \\
\hline Sampel (N) & 35 & 37 & 35 & 37 \\
\hline $\begin{array}{l}\text { Skor } \\
\text { Maksimum }\end{array}$ & 18 & 17 & 30 & 28 \\
\hline Skor Minimum & 1 & 1 & 7 & 1 \\
\hline Rerata Skor & 10,57 & 9,86 & 17,91 & 13,24 \\
\hline Skor Ideal & 40 & 40 & 40 & 40 \\
\hline $\begin{array}{l}\text { Standar } \\
\text { Deviasi }\end{array}$ & 4,33 & 3,57 & 5,57 & 6,85 \\
\hline $\begin{array}{l}\text { \% } \\
\text { Ketercapaian } \\
\text { dari skor ideal }\end{array}$ & $26 \%$ & $25 \%$ & $45 \%$ & $33 \%$ \\
\hline
\end{tabular}

Adapun grafik perolehan skor rata-rata tes awal dan tes akhir dari kedua kelas dapat dilihat pada gambar 1 .

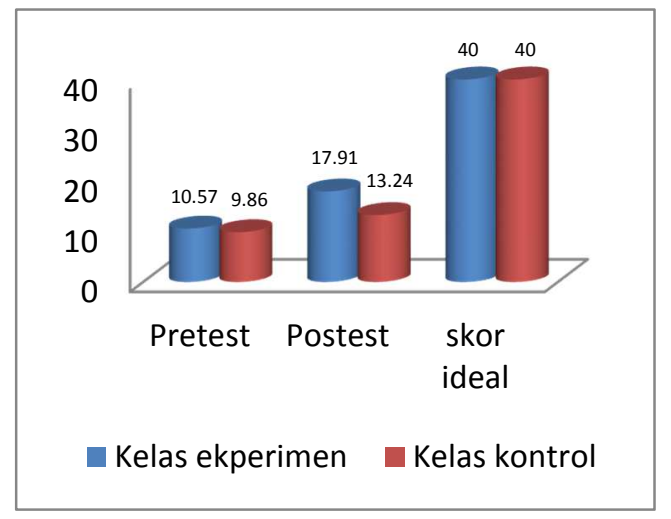

Gambar 1. Grafik perolehan rata-rata skor tes awal dan tes akhir kemampuan memecahkan masalah.

Berdasarkan gambar 1 perolehan skor rata-rata siswa secara kuantitas terdapat perbedaan. Pada postest perbedaan yang ditunjukkan cukup signfikan dimana kelas eksperimen dengan peolehan skor tertinggi yaitu 17,91 sedangkan pada kelas kontrol dengan perolehan skor yaitu 13,24. Pada tabel 2 persentase skor rata-rata tes ketercapaian kemampuan memecahkan masalah fisika pada tes awal dan tes akhir yang diukur dari skor ideal yakni skor rata-rata dibagi dengan skor ideal yang dikalikan dengan $100 \%$ diperoleh pada tes awal (pretest ) kelas ekperimen 26\% dan kelas kontrol $25 \%$, sedangkan untuk tes akhir (postest) pada kelas ekperimen $45 \%$ dan kelas kontrol 33\%. Secara kuantitas terdapat perbedaan kemampuan siswa dalam memecahkan masalah fisika antara kelas eksperimen dan kelas kontrol.

\section{b. Hasil Uji Hipotesis}

Berdasarkan hasil uji normalitas dan uji homogenitas yang telah dilakukan, diperoleh data yang berdistribusi normal dan homogen pada taraf signifikansi 0,05. Atas dasar tersebut dapat dilakukan uji kesamaan rata-rata dengan menggunakan uji signifikansi (dua pihak). Uji ini digunakan untuk memastikan apakah hipotesis yang diajukan dapat diterima atau ditolak. Hasil perolehan pengujian statistik uji signifikansi data hasil kemampuan siswa dalam memecahkan masalah fisika antara kelas eksperimen dan kelas kontrol ditunjukkan pada Tabel 2 .

Tabel 2 : Uji signifikansi (dua pihak) tes awal (pretest) dan tes akhir (postest) kelas ekperimen dan kelas kontrol

\begin{tabular}{|c|c|c|c|c|c|c|c|}
\hline \multirow{2}{*}{ Kelas } & \multicolumn{2}{|c|}{$\begin{array}{c}\text { Nilai Rata- Rata } \\
\bar{X}\end{array}$} & \multicolumn{2}{|c|}{$\mathrm{t}_{\text {Hitung }}$} & \multirow{2}{*}{$\begin{array}{l}t_{\text {tabel }} \\
(\alpha= \\
0,05)\end{array}$} & \multicolumn{2}{|c|}{ Keputusan } \\
\hline & Pretest & $\begin{array}{l}\text { Poste } \\
\text { st }\end{array}$ & $\begin{array}{l}\text { Pret } \\
\text { est }\end{array}$ & $\begin{array}{l}\text { Post } \\
\text { est }\end{array}$ & & $\begin{array}{l}\text { Pret } \\
\text { est }\end{array}$ & $\begin{array}{c}\text { Post } \\
\text { est }\end{array}$ \\
\hline $\begin{array}{c}\text { Eksperimen } \\
\text { (XI IPA-A) }\end{array}$ & 10,57 & 17,91 & \multirow{2}{*}{0,76} & \multirow{2}{*}{3,18} & \multirow{2}{*}{1,99} & \multirow{2}{*}{$\begin{array}{c}\mathrm{H}_{\circ} \\
\text { Diter } \\
\text { ima }\end{array}$} & \multirow{2}{*}{$\begin{array}{c}\mathrm{H}_{1} \\
\text { Diter } \\
\text { ima }\end{array}$} \\
\hline $\begin{array}{c}\text { Kontrol } \\
\text { (XI IPA-F) }\end{array}$ & 9,86 & 13,24 & & & & & \\
\hline
\end{tabular}

Berdasarkan tabel 2 terlihat bahwa, pada tes awal (pretest) nilai thitung sebesar 0,76 dan nilai $t_{\text {tabel }}$ pada taraf signifikansi $(a=0,05)$ sebesar 1,99 hasil pengujian ini menunjukkan $t_{\text {hitung }}$ berada pada daerah penerimaan $\mathrm{H}_{0}$, yakni thitung $<t_{\text {tabel }}$ dengan demikian $\mathrm{H}_{0}$ diterima dan $\mathrm{H}_{1}$ ditolak artinya tidak terdapat perbedaan kemampuan memecahkan masalah fisika antara kelas eksperimen dan kelas kontrol.

Untuk pengujian hipotesis berdasarkan tes akhir (postest) diperoleh nilai sebesar 3,18 dan nilai tabel pada taraf signifikansi ( $a=0,05)$ sebesar 1,99 hasil pengujian ini menunjukkan thitung berada pada daerah penerimaan $\mathrm{H}_{1}$, yakni $t_{\text {hitung }} \geq t_{\text {tabel }}$ dengan demikian 
$\mathrm{H}_{1}$ diterima dan $\mathrm{H}_{0}$ ditolak artinya terdapat perbedaan kemampuan memecahkan masalah fisika antara kelas eksperimen dan kelas kontrol.

Penelitian ini bertujuan untuk menguji signifikansi pengaruh model pembelajaran creative problem solving terhadap kemampuan siswa dalam memecahkan masalah fisika dengan melihat perbedaan kemampuan siswa dalam memecahkan masalah fisika antara kelas eksperimen dan kelas kontrol pada hasil analisis postest. Sebelum dilakukan analisis postest dilakukan juga analisis pada hasil pretest karena hasil pretest digunakan untuk melihat keadaan awal kedua kelas apakah memenuhi syarat sebagai sampel penelitian atau tidak.

Berdasarkan hasil analisis kualitatif pretest kemampuan memecahkan masalah fisika menunjukkan skor rata-rata siswa kelas eksperimen 10,57 dengan standar deviasi 4,33 dan skor ratarata kelas kontrol 9,86 dengan standar deviasi 3,57. Hasil ini menunjukkan bahwa terdapat perbedaan skor antara kelas eksperimen dan kelas kontrol terlihat bahwa skor kelas eksperimen lebih tinggi dibandingkan kelas kontrol. Hasil ini berbeda dengan hasil analisis uji statistik pada pengujian hipotesis dengan menggunakan rumus Uji-t dua pihak pada taraf $a=0,05$. Dari perhitungan hipotesis diperoleh $t_{\text {hitung }}$ sebesar 0,76 dan $t_{\text {tabel }}$ sebesar 1,99. Hasil pengujian hipotesis menunjukkan bahwa $t_{\text {hitung }}<t_{\text {tabel }}$ yaitu $0,76<1,99$ dengan kata lain hipotesis $H_{0}$ diterima dan $\mathrm{H}_{1}$ ditolak. Berdasarkan hasil pengujian hipotesis menunjukkan bahwa tidak terdapat perbedaan memecahkan masalah fisika antara kelas eksperimen dan kelas kontrol. Kemampuan dalam memecahkan masalah baik dikelas eksperimen maupun dikelas kontrol tidak terdapat perbedaan yang menjadikan kedua kelas ini memenuhi syarat sebagai sampel penelitian.

Analisis postest menunjukkan hasil yang berbeda, terlihat bahwa hasil analisis kualitatif kemampuan memecahkan masalah fisika menunjukkan skor rata-rata siswa kelas eksperimen 17,91 dengan standar deviasi 5,57 dan skor ratarata kelas kontrol 13,24 dengan standar deviasi
6,85. Hasil ini menunjukkan bahwa terdapat perbedaan skor antara kelas eksperimen dan kelas kontrol terlihat bahwa skor kelas eksperimen lebih tinggi dibandingkan kelas kontrol. Hasil ini juga didukung oleh analisis uji statistik pada pengujian hipotesis dengan menggunakan rumus Uji-t dua pihak dengan dk $\left(n_{1}+n_{2}-2\right)$ dengan taraf $a=0,05$. Dari perhitungan hipotesis diperoleh thitung sebesar 3,18 dan tabel sebesar 1,99. Hasil pengujian hipotesis menunjukkan bahwa $t_{\text {hitung }} \geq t_{\text {tabel }}$ yaitu $3,18 \geq 1,99$ dengan kata lain hipotesis $\mathrm{H}_{1}$ diterima. Berdasarkan hasil pengujian hipotesis dapat disimpulkan bahwa ada pengaruh model pembelajaran creative problem solving secara signifikan terhadap kemampuan siswa dalam memecahkan masalah fisika pada materi elastisitas dan gerak harmonik sederhana kelas XI SMA Negeri 4 Palu.

Pada skor akhir (postest) pada kelas eksperimen dan kelas kontrol cukup berbeda. Rata-rata skor untuk kelas eksperimen sebesar 17,91 sedangkan kelas kontrol sebesar 13,24. Secara kuantitas hasil ini menunjukkan perbedaan yang signifikan harga tersebut menunjukkan kelas eksperimen memperoleh skor rata-rata yang tinggi dibandingkan dengan kelas kontrol. Diperolehnya hasil tersebut dimungkinkan karena dalam pembelajaran menggunakan model creative problem solving, siswa berperan aktif dalam proses pembelajaran dan secara kreatif berusaha menemukan solusi dari permasalahan yang diajukan, saling berinteraksi dengan teman maupun guru, saling bertukar pikiran, sehingga wawasan dan daya pikir mereka berkembang dan menyadari banyak hal atau kejadian yang dapat mereka jumpai dalam kehidupan sehari-hari yang berkaitan dengan konsep fisika yang mereka pelajari. Salah satu contoh pada materi elastisitas dimana peneliti menanyakan: "karet dan tanah liat adalah benda yang sering kalian jumpai dalam kehidupan sehari-hari, jika kedua benda tersebut kita beri gaya tarik benda tersebut akan mengalami perubahan bentuk. Benda manakah yang dapat kembali ke bentuk semula setelah gaya yang diberikan dihilangkan?". Secara antusias siswa menjawab pertanyaan yang diberikan sesuai yang 
mereka lihat dalam kehidupan sehari-hari. Kemudian peneliti meneruskan dengan pertanyaan: "dari kedua benda tersebut manakan benda yang bersifat plastis dan benda yang bersifat elastis?". Disini terjadi perdebatan antara siswa sehingga menjadikan mereka penasaran dengan jawaban yang sebenarnya. Peneliti belum memberikan jawaban melainkan melanjutkan dengan memberikan materi tentang elastisitas guna menanamkan konsep yang diperlukan untuk menyelesaikan masalah yang dihadapi. Setelah siswa telah memahami dengan materi elastisitas kemudian peneliti menanyakan kembali tentang pertanyaan awal yang menghadirkan kontra dan secara langsung siswa menjawab pertanyaan tersebut sesuai dengan konsep yang diajarkan. Pada tahap ini siswa menyadari akan banyak hal dan menyadari akan makna dari belajar fisika.

Tahap selanjutnya yaitu tahap inti dari model creative problem solving dimana siswa dituntut untuk berdiskusi kelompok guna bertukar pikiran dalam menghasilkan beragam ide-ide permasalahan yang mereka jumpai dalam kehidupan sehari-hari dan bagaimana menyelesaikan permasalahan tersebut berdasarkan konsep yang telah mereka pelajari. Salah satu ide masalah yang mereka peroleh pada penerapan elastisitas dalam kehidupan sehari-hari yaitu "mengapa pemasangan kabel PLN harus dibuat kendur?". Siswa mencoba menjawab pertanyaan tersebut secara berkelompok dan mencoba menggunakan literatur yang ada guna mendukung dalam menyelesaikan permasalahan yang dihadapi. Jika dilihat pertanyaan ini memunculkan kontra karena permasalahan ini bisa diselesaikan dengan konsep pemuaian dan juga bisa dengan konsep elastisitas tetapi secara kreatif siswa mampu menyelesaikan masalah tersebut dengan konsep elastisitas. Pada tahap ini siswa mampu mengembangkan ide, wawasan dan kreatifitas mereka yang menjadikan mereka menjadi aktif dalam proses pembelajaran dan yang utamanya adalah mereka mendapatkan makna dari belajar ilmu fisika yang ternyata dapat bermanfaat dalam kehidupan sehari-hari. Hasil ini sejalan dengan kelebihan dengan problem solving yang ada pada literatur dimana siswa diantaranya mampu menyelesaikan masalah secara realistis dan berpikir serta bertindak secara kreatif.

Model pembelajaran creative problem solving merupakan model pembelajaran yang berpusat pada masalah yang menekankan dalam keseimbangan antara pemikiran divergen dan pemikiran konvergen selain itu model pembelajaran creative problem solving juga dapat meningkatkan aktifitas dan berpikir kreatif siswa serta berpikir kritis dalam proses pembelajarannya. Penelitian model pembelajaran creative problem solving di SMA Negeri 4 Palu memiliki pengaruh signifikan dibandingkan dengan model pembelajaran konvensional. Terlepas dari semua itu, peneliti juga memperoleh beberapa hambatan berdasarkan pengamatan dalam proses pembelajaran creative problem solving diantaranya: (a) Tujuan dari dibentuknya kelompok-kelopok kecil belum telaksana secara keseluruhan dimana siswa cenderung mendiskusikan hal-hal diluar materi pelajaran bila siswa tidak diawasi. (b) Siswa masih menemukan hambatan dalam menemukan ide-ide permasalahan maupun dalam memecahkan masalah yang dihadapi hal ini disebabkan karena sumber belajar yang masih kurang sehingga siswa cukup kesulitan dalam menemukan informasi-informasi yang dibutuhkan dalam memecahkan masalah. (c) Seperti halnya kekurangan pada problem solving pada literatur, peneliti juga merasakan bahwa dalam pembelajaran pemecahan masalah seperti creative problem solving memang membutuhkan alokasi waktu yang cukup lama. Selain itu tidak semua pokok bahasan cocok dengan model ini seperti yang terjadi pada pokok bahasan gerak harmonik sederhana siswa menemukan kesulitan dalam menghasilkan ide-ide permasalahan yang biasa dijumpai dalam kehidupan sehari-hari yang berkaitan dengan materi gerak harmonik sederhana.

\section{KESIMPULAN}

Berdasarkan hasil postest kemampuan memecahkan masalah fisika menunjukkan skor ratarata siswa kelas eksperimen sebesar 17,91 dengan 
standar deviasi 5,57 dan skor rata-rata kelas kontrol sebesar 13,24 dengan standar deviasi 6,85. Pengujian hipotesis dilakukan dengan menggunakan rumus Uji-t dua pihak dengan dk $\left(n_{1}+n_{2}-2\right)$ pada taraf $a=0,05$. Perhitungan hipotesis diperoleh $t_{\text {hitung }}$ sebesar 3,18 dan tabel sebesar 1,99. Hasil pengujian hipotesis menunjukkan bahwa $t_{\text {hitung }} \geq t_{\text {tabel }}$ yaitu 3,18 $\geq 1,99$ dengan kata lain hipotesis $H_{1}$ diterima. Berdasarkan hasil pengujian hipotesis tersebut dapat disimpulkan bahwa terdapat pengaruh model pembelajaran creative problem solving secara signifikan terhadap kemampuan siswa dalam memecahkan masalah fisika pada materi elastisitas dan gerak harmonik sederhana kelas XI SMA Negeri 4 Palu.

\section{DAFTAR RUJUKAN}

[1] Taufik, Sukmadinata, Abdulhak, Tumbelaka. 2010. Desain Model Pembelajaran untuk Meningkatkan Kemampuan Pemecahan Masalah dalam Pembelajaran Ipa (Fisika) Sekolah Menengah Pertama di Kota Bandung. Berkala Fisika. Vol 13. , No.2, Edisi khusus, hal E31-E44

[2] Departemen Pendidikan Nasional. 2006. Kurikulum Tingkat Satuan Pendidikan Sekolah Menegah Atas. Jakarta. Depdiknas.

[3] Santyasa. (2007). Pengembangan Pemahaman Konsep Dan Kemampuan Pemecahan Masalah Fisika Bagi Siswa SMA Dengan Pemberdayaan Model Perubahan Konseptual Berseting Investigasi Kelompok. Jurnal Pendidikan Fisika Universitas Pendidikan Ganesha.

[4] Noortsani (2013). Peningkatan Kemampuan Pemahaman dan Pemecahan Masalah Matematis Siswa SMA di Kabupaten Cianjur Melalui Pendekatan Creative Problem Solving. Universitas Pendidikan Indonesia. Perpustakaan.upi.edu.

[5] Nur Hidayati, A. 2012. Efektivitas Model Pembelajaran direct instruction Terhadap Hasil Belajar Matematika. Skripsi Fakultas Tarbiyah Institut Agama Islam Negeri Walisongo Semarang: Tidak diterbitkan.

[6] Sugiyono. 2009. Metodelogi Penelitian Pendidikan (Pendekatan Kuantitatif,. Kualitatif, dan R\&D). Bandung: Alfabeta. 